\section{TÓPICOS ICONOGRÁFICOS Y CULTURA MATERIAL EN UNA RELACIÓN DE FIESTAS NOVOHISPANA DE 1621}

\author{
Eva Valero Juan \\ Universidad de Alicante \\ ORCID iD: https://orcid.org/0000-0002-4671-5533 \\ Eva.Valero@ua.es
}

Cómo citar este artículo/Citation: Valero Juan, E. (2020). Tópicos iconográficos y cultura material en una relación de fiestas novohispana de 1621. Arbor, 196 (797): a564. https:// doi.org/10.3989/arbor.2020.797n3001

\section{ICONOGRAPHIC TOPICS AND MATERIAL CULTURE IN A RELACIÓN DE FIESTAS IN MEXICO IN 1621}

Copyright: (C) 2020 CSIC. Este es un artículo de acceso abierto distribuido bajo los términos de la licencia de uso y distribución Creative Commons Reconocimiento 4.0 Internacional (CC BY 4.0).
RESUMEN: Si en las relaciones de fiestas virreinales la profusa descripción de todos los elementos que revisten el acontecimiento es una de sus marcas de estilo, el texto de 1621 titulado Verdadera relación de una máscara que los artífices del gremio de la platería de México y devotos del glorioso San Isidro hicieron en honra de su gloriosa beatificación resulta paradigmático sobre la relevancia de la cultura material para la construcción de la imagen de Carlos $V$ y de todos los elementos del desfile. Los vestidos, las alhajas, los objetos son centrales para la edificación iconográfica del mito del héroe y para propagar la imagen heroica de España. El presente trabajo analiza tanto esta cultura material que el texto retrata como su dimensión con respecto a la recepción en América de personajes literarios e históricos y la especial significación que el contexto les imprime.

PALABRAS CLAVE: Relación de fiestas; México; cultura material; Colonia.
ABSTRACT: If in the relaciones de fiestas, one of the identifying styles is the profuse description of all the elements that cloak the event, the text from 1621 entitled Verdadera relación de una máscara que los artífices del gremio de la platería de México y devotos del glorioso San Isidro hicieron en honra de su gloriosa beatificación is paradigmatic on the relevance of material culture to construct the image of Carlos $V$ and all the elements in the parade. The clothing, jewels, objects are central to the iconographic building of the myth of the hero and to propagate the heroic image of Spain. This work analyses both this material culture portrayed by the text and its dimension in regard to the reception of literary and historical characters in America and the special significance the context imprints on them.

KEYWORDS: Relación de fiestas; Mexico; material culture; Colonia. 


\section{INTRODUCCIÓN}

Los estudios sobre las relaciones de fiestas barrocas han revelado que tales documentos son una fuente histórico-literaria de gran potencial para profundizar en el conocimiento del entramado social, político y cultural de la sociedad española e indiana de los siglos XVI a XVIII. En el periodo del Barroco esta tipología textual proliferó de manera abrumadora para dar cuenta de todo tipo de fastos de carácter religioso, político o cívico, cuya configuración estaba plenamente destinada a la propaganda de los poderes estatales, civiles o eclesiásticos. Para dichos estudios, la perspectiva que aporta el análisis de la cultura material resulta fundamental, en tanto que los textos ponen en el centro de la escena los vestidos, las alhajas, los objetos, como manifestaciones de las actividades y de las formas de pensamiento, de las cuales se obtiene información esencial sobre los modos de vida, de organización y de conducta de la sociedad que protagonizó dichos acontecimientos.

En el texto objeto de este trabajo, titulado Verdadera relación de una máscara que los artífices del gremio de la platería de México y devotos del glorioso San Isidro el Labrador de Madrid, hicieron en honra de su gloriosa beatificación ${ }^{1}$, la ciudad se transfigura en escenario para la realización de un portentoso desfile de máscaras con motivo de la celebración de la beatificación de San Isidro Labrador. Ello nos sitúa ante una fiesta de carácter religioso, si bien obviamente en este caso no obedece a una festividad anual prefijada en el calendario religioso sino a la beatificación de San Isidro en 1621. Al año siguiente, en 1622, tendría lugar la canonización del santo, que dio lugar a otras fiestas en la Península, como por ejemplo la relatada por Lope de Vega en la Relación de las fiestas que la insigne villa de Madrid hizo en la canonización de su bienaventurado hijo, y patrón San Isidro (1622).

En el Virreinato de México este tipo de textos proliferaron desde 1560, cuando Francisco Cervantes de Salazar publicó el Túmulo imperial para las honras fúnebres de Carlos $\mathrm{V}^{2}$. Las fiestas objeto de las relaciones fueron de muy diversa índole, dependiendo del objetivo al que fueran dirigidas. Manuel Romero de Terreros, en el prólogo al libro que contiene una de las ediciones del texto que nos ocupa -Torneos, mascaradas y fiestas reales en la Nueva España-explica los distintos tipos de celebraciones de acontecimientos que se trasplantaron a México desde los orígenes de la conquista. Las mascaradas consistían en comparsas de caballeros nobles, de estudiantes de la Universidad o de gremios de artesanos, vistiendo trajes que querían representar, ya personajes históricos o mitológicos, ya las Virtudes Teologales, los Dones del Espíritu Santo, o aún los vicios del hombre; y festejábanse con ellas las juras y cumpleaños de los monarcas, los santos de los virreyes, las dedicaciones de las iglesias, la entrada pública de los virreyes y de los arzobispos, y la mayor parte de las fiestas profanas y religiosas (Romero de Terreros, 1918, p. 7).

Los textos que las relataban tenían la función de dar noticia de estas ceremonias o celebraciones públicas relacionadas con la monarquía o con el clero. En la Verdadera relación el doble carácter político-religioso de la festividad confiere un especial interés a las imágenes reveladoras del complejo entramado de la sociedad colonial y a las estampas del conjunto de naciones que acompañan a Carlos $\mathrm{V}$-el verdadero protagonista, como se verá, de esta relación-y homenajean al santo cristiano. Todo ello en su conjunto se transmite a través del concepto amplio de cultura material en el sentido apuntado por Hunter y Whitten (1981):

Cualquier ejemplo representativo de las manifestaciones de la cultura deberá incluir obras de arte, ornamentos, instrumentos de música, objetos de ritual y monedas u objetos de trueque, además de la vivienda, vestidos y medios de obtención y producción de alimentos y de transporte de personas y mercancías.

Cada objeto del inventario material de una cultura representa la concretización de una idea o secuencia de ideas (p. 201).

En el texto objeto de análisis, la fiesta como manifestación de la cultura hispánica, que pone en el centro de la escena los ornamentos, los vestidos, los instrumentos musicales y los objetos que conforman tanto la iconografía de Carlos V como todos los elementos del desfile, es significativa para esa concreción de una idea fundamental: la propagación de la imagen heroica de España en las Colonias. Esta tiene la peculiaridad de estar en dependencia directa del contexto para el que está destinada, en el que se trataba de consolidar el poder virreinal y la estructura social. La concreción ideológica es, si cabe, más significativa cuando el texto patentiza la utilización de la cultura material para la doble construcción de Carlos V, como veremos medieval y renacentista, con la que se sintetizan y concentran todos los sentidos de la conflictiva relación entre período de la conquista y periodo colonial en las puertas del siglo XVII. 
Por último, cabe subrayar en esta introducción al análisis del texto que, si bien el motivo de la fiesta es de signo religioso, la entidad organizadora no es la Iglesia sino el gremio de la platería, lo cual era habitual en este contexto histórico, tal y como explica Francisco de Solano (1990):

Alcanzan un carácter diferente, por su entidad gremial, las fiestas o devociones promovidas por las asociaciones laborales de pintores, cereros y tintoreros, sederos, plateros, sastres y escribanos, que relatan actos en honor de sus patronos: Espíritu Santo, San Isidro, San Eligio, San Homobono, San Juan Evangelista (p. 255).

Este punto de partida resulta imprescindible para notar que, a pesar de ser una fiesta popular, ello no impide que tanto lo político como lo religioso sean centrales, de modo que se traban y fortalecen vínculos entre el gremio, la fiesta de los nobles y la fiesta religiosa, que aseguran la penetración del discurso del poder en el ámbito de lo popular. De hecho, a pesar de que el título establece como "artífices" de la fiesta a los miembros del "gremio de la platería de México", sin embargo, las primeras líneas del texto enfocan y confieren protagonismo al poder, en tanto que hacen aparecer como organizadores de otras celebraciones previas en honor de San Isidro a un arzobispo y a un marqués. De este modo, ambas figuras representantes de los poderes religioso y político aparecen desde el inicio cumpliendo una suerte de función tutora de la nueva festividad en honor al santo.

\section{EL ESPACIO URBANO COMO ESCENARIO FESTIVO}

En el contexto hispánico, el simbolismo de las fiestas tuvo una relevancia fundamental para la concepción del espacio urbano, es decir, para la configuración de las ciudades cuya plaza fue el corazón aglutinador de la sociedad y el centro de la vida social. La conversión de la ciudad en espacio para la fiesta suponía la transformación de sus calles, plazas, edificios, etc. en un escenario que, en los días festivos, relegaba sus funciones civiles para entregarse al boato, las representaciones, los desfiles... en definitiva, a la diversión.

El protagonismo de la ciudad-teatro alcanzó su máximo apogeo en el período histórico del Barroco ${ }^{3}$, cuando la fiesta como espectáculo político se construyó sobre unas bases ideológicas cuya función semiótica resultó ser determinante para la glorificación de los monarcas o, en el ámbito hispanoamericano, también de sus respectivos vicarios (cfr. Buxó, 2007, pp. 49-50). Al igual que sus actores, en el período de la fiesta la ciudad también se disfrazaba. Su paisaje humano y su teatro urbano -entendido este último como el escenario físico y el entramado social de la ciudad-crearon una alianza para abandonar las funciones cotidianas durante un tiempo determinado en el que el regocijo se adueñaba de todas sus piezas, convirtiéndose en el lenitivo principal del sistema estatuido para asegurar y afianzar el funcionamiento de la estructura social. El objetivo de esta conversión del espacio urbano resulta muy claro cuando nos acercamos a los textos festivos barrocos: la ciudad se engalanaba para hacer olvidar a sus habitantes, convertidos en espectadores o protagonistas de la fiesta, las miserias cotidianas.

Para visualizar ese entramado, el concepto de cultura material cobra toda su relevancia en los elementos que conciernen a la festividad, partiendo de la idea del propio escenario de la misma, la ciudad, pues la imagen virtual que generaba este "engaño a los ojos" produjo en el Barroco las más espectaculares transformaciones urbanas que hasta entonces se hubieran visto ${ }^{4}$. Como apunta Antonio Bonet Correa (1986),

en una época tan urbana y de masas como fue el barroco la fiesta tenía que revestir forzosamente una apariencia de por sí artificiosa. La Europa de las capitales -Roma, Viena, París, Praga, Nápoles, Palermo, Turín, etc...- no podía concebir la fiesta como una alteración epidérmica de su ser permanente. Otro tanto sucedió en Madrid, México, Lima o Quito. La ciudad metropolitana llevaba a cabo fiestas dignas de su grandeza, poder y riqueza. Las fiestas serían su mejor corona y emblema. De ahí que la disposición misma de la ciudad se adaptase y adoptase formas propias, capaces de llevar a cabo sin dificultades su mutación teatral en escenario de fiestas (p. 57).

En este sentido, y siguiendo el eje propuesto para el análisis del texto en lo que respecta a la materialidad de los elementos de la fiesta, es preciso recordar que "a través del estudio de la cultura material, el historiador puede ser capaz de llegar a conocer al hombre de su época; porque es en las relaciones sociales donde hay que buscar la significación de los hechos materiales" (Sarmiento Ramírez, 2007, p. 221). Y sin duda las fiestas son un momento de apogeo tanto de las relaciones sociales como de la puesta en escena de elementos materiales para la construcción de las ideas. En el México colonial, y en concreto en su capital, este fenómeno tuvo numerosísimas manifestaciones, una verdadera proliferación de actos festivos que se celebraban en el escenario de la sede del gran virreinato de la Nueva España, a imagen de las grandes fiestas peninsulares. 


\section{LA CULTURA MATERIAL AL SERVICIO DEL ORDEN MONÁRQUICO-CATÓLICO}

Desde el comienzo del desfile se edifica materialmente la imagen del poder en diferentes figuraciones que serán objeto de análisis, para salvaguardar el orden monárquico-católico y asegurar la eficacia propagandística que en este texto resulta de especial relevancia. Partiendo de esa mirada de los poderes públicos que el autor de la relación -Juan Rodríguez Abril- destaca en las primeras líneas del texto, un recorrido por sus diferentes partes permite desentrañar las claves y los símbolos que hacen de este texto un emblema de la propaganda imperial, disfrazada bajo el palio de una beatificación y realizada visualmente a través de la cultura material, así como enfocar el potencial significativo de un texto tan rico en mensajes subliminales y en claves de interpretación del trasfondo social, político y cultural del mundo colonial en que se desarrollan.

En la Verdadera relación el espacio de la ciudad aparece desde las primeras líneas como el escenario teatral para la celebración: "salió a pasear las calles del patio de las casas del Mariscal, que están enfrente del convento de San Francisco, dando principio a ella una figura de la Fama"; líneas que sitúan la fiesta en los lugares más añosos de la urbe, si tenemos en cuenta que el convento de San Francisco es uno de los edificios más antiguos de la capital mexicana. José Rojas Garcidueñas (1972) reconstruyó el hipotético recorrido de esta cabalgata por la ciudad:

[...] no creo equivocarme mucho en suponer el recorrido del cómico desfile: partiendo de la casa del Mariscal de Castilla, que estaba en la esquina de las hoy Avenida Hidalgo y calle Aquiles Serdán, contraesquina de la Oficina Central de Correos, el cortejo debe de haber seguido por San Juan de Letrán y Av. Madero hasta desembocar en la Plaza Mayor, la que recorrería, como era costumbre, pasando frente a las Casas del Cabildo (hoy Departamento Central), el Palacio Real (hoy Palacio Nacional), la Catedral, luego la Plazuela del Marqués (hoy calle del Monte de Piedad)... (pp. 100-101).

En ese escenario da inicio el desfile con la aparición de la Fama, en su función de voz pública, y con ella comienza a focalizarse la materialización cultural de la imagen a través de la descripción de la indumentaria propia de su representación mitológica, anunciando la fiesta: iba "en un caballo blanco con vestidura de tela rosada y tocado vistoso, de donde pendía un velo de plata, cuya caída paraba sobre las ancas del cabaIlo, con muy volantes alas de varias plumas y sono- ra trompa en los labios"5. Tras ella sigue "un bizarro labrador" enmascarado, engalanado y revestido de oro en medio de un campo repleto de todo tipo de piedras preciosas sobre el que el relator nos dice "que no es posible hacer suma de su riqueza". El estilo superlativo propio de las relaciones de acontecimientos comienza así a actuar para dar entrada triunfal al personaje simbólico del homenajeado, el santo labrador, que no solo aparece representado con una imagen de gran esplendor, sino que además lleva en su mano "las armas de Madrid". La propaganda imperial se hace presente con esta estampa inicial del desfile, que se ve de inmediato engrandecida por el séquito glorioso que lo antecede: "todos los caballeros andantes autores de los libros de caballerías". La solemnidad de esta pléyade de caballeros provenientes de la ficción medieval europea se ve alterada por los personajes que cierran el desfile de este primer grupo: don Quijote, Melia la Encantadora, Urganda la Desconocida en dos camellos, los Enanos Encantados sobre dos avestruces, Sancho Panza y Dulcinea del Toboso. Lo ridículo y carnavalesco que tal grupo representa introduce la disonancia en el seno de la escenificación solemne, no solo a través de la aparición de don Quijote, sino sobre todo por la explícita representación paródica de Sancho y Dulcinea, materializada en sus disfraces: "que a rostros descubiertos, los representaban dos hombres graciosos, de los más fieros rostros y ridículos trajes que se han visto". El travestismo de la imagen y la bufonada de los trajes enfatizan el efecto irrisorio. Pero además hay otro dato trascendental para la interpretación de esta estampa quijotesca en una relación americana de comienzos del siglo XVII, y es que don Quijote aparece en medio de esta hornada de caballeros andantes como el "más moderno" del mundo de la caballería. Marchaban

todos los caballeros andantes autores de los libros de caballerías, Don Belianís de Grecia, Palmerín de Oliva, el caballero del Febo, etc., yendo el último, como más moderno, Don Quijote de la Mancha, todos de justillo colorado, con lanzas, rodelas y cascos, en caballos famosos; [...] y últimamente a Sancho Panza, y doña Dulcinea del Toboso...

La paradoja que implica la modernidad de don Quijote salta a la vista si imaginamos el aspecto anacrónico del personaje en medio de este cuadro caballeresco. La escena -cuya configuración cómica se ve intensificada por los enanos subidos en avestruces, etc.- cumple la función de ruptura de un discurso de intensa propaganda imperialista, que entreteje todos los elementos del desfile. Esta ruptura es esencial 
para interpretar la significación histórica de los personajes cervantinos en medio de este desfile americano, en tanto que acerca la fiesta elitista al ámbito de lo popular a través de la inversión del héroe caballeresco representada en la figura de don Quijote. Su modernidad radica, precisamente, en la liquidación del mundo heroico que él mismo personifica dentro de un desfile profundamente codificado desde el punto de vista propagandístico de ese mismo mito parodiado por don Quijote.

Tras el cuadro quijotesco, sigue otro labrador que introduce el elemento literario, pero también el primer mensaje de estratificación social, puesto que además de portar el cartel con "una octava que declaraba el pensamiento de la máscara", aparece acompañado por "doce mancebos de traje y rostro guinea", con lo que el desfile incorpora el componente africano en su rol de sojuzgamiento en una fiesta hispánica -algo por otro lado muy usual en los fastos peninsulares-. Además, hay un segundo grupo de acompañantes: las armas eran llevadas por doce caballos a los que también se disfraza, en su caso, de toros, con tanto verismo que "a la vista parecieron naturales toros". Con esta última apreciación del relator, el "engaño a los ojos" tan propio del Barroco cobra toda su dimensión, puesto que su materialización a través del disfraz logra dar apariencia natural al artificio. Y el narrador hace hincapié en la impresión que tal invención causó, "por ser cosa nunca vista en las Indias". Este afán de impresionar a través de todos los recursos visuales cobra solidez con la utilización de elementos simbólicos del poder de España como son el caballo, el toro y las armas.

Si recapitulamos, hemos visto cómo la mitología clásica -con la figura de la Fama-, el imaginario de los libros de caballerías, diferentes elementos de la cultura hispánica y el aporte africano se han dado cita en el espacio aglutinador del México virreinal. El desfile relatado por Juan Rodríguez se desenvuelve en una constante fluctuación entre ambas esferas de la realidad que crea una interesantísima fusión entre el discurso popular y el discurso del poder. Este último adquiere una especial trascendencia en la aparición del siguiente grupo de la cabalgata, que protagoniza una escena en la que se representa la coronación del imperio romano, con la participación de muy galanes caballeros de diferentes naciones -evidentemente montando a caballo como símbolo de poder-, seis reyes de armas con deslumbrantes vestidos y las armas imperiales. La coronación hace referencia al Sacro Imperio Romano Germánico, pues en el mismo cuadro aparecen los electores del imperio (el conde Palatino del Rin, el duque de Sajonia, el marqués de Brandenburgo) y los arzobispos de Tréveris, de Colonia -portando los sellos de oro que significaban las tres coronaciones de Carlos $\mathrm{V}^{6}$ - y de Maguncia -este último llevando el sello del Imperio-. Con este cuadro el mundo europeo aparece en todo el esplendor que materializan los objetos para mostrar en el territorio de las colonias la omnipotencia de la monarquía española que conquistó América en los tiempos del gran Imperio de Carlos V. El mito del héroe y del Imperio se construye de este modo en el texto para fijar la iconografía imperial y propagar la imagen heroica de España ya en tiempos de la estabilidad colonial.

Esta presentación del Imperio antecede a la figura central del desfile, Carlos V, que hace su aparición triunfal a continuación en una representación que obedece a los tópicos iconográficos fijados durante todo el siglo XVI, con los que las artes edificaron la imagen oficial de la dignidad imperial:

Luego, después de mucha guardia y archeros con lucidas libreas, iba en un hermosísimo caballo el emperador de Alemania, armado de muy lucidas armas, sin manoplas, con una capa de coro de brocado sin capilla, con riquísima corona imperial de piedras preciosas, oro y perlas, y en la mano izquierda, encima de un bastón, llevaba un globo y en la derecha el cetro.

La imagen, intensamente codificada desde el punto de vista material en lo que a la indumentaria y los objetos se refiere, responde en buena medida a los retratos alegóricos del manierismo italiano realizados a partir de 1530: el Emperador aparece vestido a la clásica, en atuendo militar, con el bastón de mando - símbolo militar- y el cetro -símbolo de la dignidad imperial e insignia característica de los reyes-, con la bola del mundo y la corona imperial, a cuyos valores sagrados provenientes de la Edad Media se unen los bélicos originarios del mundo romano (Checa Cremades, 1987, pp. 235-237). Los símbolos que revisten la imagen son por tanto muy significativos de la propaganda que este desfile transmite con especial énfasis. La imagen aúna las dos visiones características de la iconografía heroico-militar de Carlos V, entre lo medieval y lo renacentista: la del espíritu caballeresco y la del mito del héroe clásico.

El dominio del mundo por parte del emperador que gobernó el Imperio durante el período de la conquista de México, como imagen histórica mitificadora del monarca que desde ultramar presidió la fundación de la Nueva España, se mostraba de esta forma por las 
calles de México a toda la población como recuerdo de un origen glorioso. De este modo, la representación del poder político adquiría mayor protagonismo que el motivo generador de la fiesta: la beatificación de un santo; si bien en todo momento se patentiza el matrimonio indisoluble entre el poder político y el religioso, pues el emperador va seguido del cardenal, y después de todos los embajadores de los reyes, el último de los cuales es el de España. Este portaba otro objeto fundamental para la lectura del texto en las claves que aporta la cultura material: el Toisón de Oro, símbolo religioso que hace referencia a la orden civil y de caballería que lleva ese nombre ${ }^{7}$; objeto que codifica la idea relativa a la dimensión medieval y caballeresca del desfile. En este sentido debemos recordar que durante el reinado de Carlos V las fiestas de la Orden del Toisón de Oro constituían el momento más importante en el devenir de la vida cortesana, y su celebración obedecía a un ceremonial muy sistematizado a través de una serie de alusiones histórico-mitológico-bíblicas fundamentales para la configuración de Carlos V como héroe renacentista, construida sobre la figura del caballero medieval. Como explica Fernando Checa, "en estos ritos, ataviado lujosamente, rodeado de sus caballeros y blasones, el Emperador aparecía como la perfecta encarnación del caballero medieval" (Checa Cremades, 1987, p. 192), en un ceremonial que a la vez es religioso y cortesano, de modo que el desfile relatado por Juan Rodríguez se edifica sobre reminiscencias de las fiestas de la Orden del Toisón, su heráldica y su procesión.

Por último, a las galas con que todos los personajes van recubiertos hay que añadir la "gran pompa de criados" que les acompañan, de manera que la imagen sigue abundando en la estructura social y, aunque no explicita la procedencia de dichos criados, podemos imaginar que estos serían los indígenas que usualmente eran integrados en las fiestas virreinales en estos papeles.

Con la imagen de Carlos V encabezando este grupo sigue a continuación el desfile, al son de las chirimías, con la aparición de otros personajes representando a los reyes de diferentes naciones. Así, la glorificación de la imagen mítica de Carlos $V$ se completa en este fragmento con la recreación de su representación clásica: como Rey de Reyes (Maravall, 1960) y como Emperador universal -tal y como apareció en las Cortes de Valladolid en 1523-. Hacen su entrada entonces una serie de figuras históricas como son el rey de Inglaterra, también muy codificadas desde el punto de vista material, con la indumentaria propia de su ran- go, descrita con la mayor prolijidad y exageración de atributos, o el gran duque de Moscovia, emperador de Rusia, también con sus galas y sus criados. Entre ellos, y con una significación especial para la transmisión de la idea de dominio mundial, aparecen los dos contendientes históricos principales de Carlos V: el rey de Francia y el Gran Turco. Juan Rodríguez describe al rey de Francia -Francisco I en época de Carlos V-con la misma magnificencia: "El rey de Francia con calza, vaquero y capa de tela verde, guarnición de oro y vueltas de tela de oro, corona de rayos, cuya hermosura podía causar envidia a los del sol". Finalmente concluye esta escena el Gran Turco, acompañado de su sultana. Así, Solimán el Magnífico -conocido en toda Europa como el Gran Turco-, que fue el monarca que llevó al Imperio Otomano a su mayor esplendor y expansión en Europa, convirtiéndose en el gran rival de Carlos $\mathrm{V}$ en la lucha por el trono del mundo, aparece como uno más entre la pléyade de reyes que acompañan al Emperador, sin duda como imagen conclusiva de la omnipotencia mundial de este último. Además, el cierre de este segmento de la cabalgata con la aparición del principal monarca otomano debe leerse no solo en clave política sino también en relación con el motivo del homenaje, la beatificación de San Isidro, en tanto que con la introducción del Gran Turco los organizadores de la fiesta estaban lanzando al público mexicano su particular mensaje religioso que se pretendía universalizar: incluso el mundo musulmán y su principal valedor acompañaban al Emperador y celebraban a un santo español.

Pero el desfile de los grandes no concluye con esta imagen imprescindible del Turco sino que continúa con la aparición de otros reyes y personajes célebres que apuntan a un recorrido por la geografía mundial dirigido desde Europa hacia el Oriente. Sigue a continuación el rey de Persia, a quien sucede un personaje mítico: el Preste Juan de las Indias, el mítico reysacerdote supuestamente descendiente de los Reyes Magos, de quien se creía que su poder era tal que había vencido al Islam, que poseía inmensas riquezas y que además era cristiano. Con el paso de los siglos se convirtió en una leyenda viva con la que soñaron misioneros, caballeros y navegantes (Gil, 1989, pp. 366$367)^{8}$. De este modo, el imaginario medieval que estuvo en la base cultural del descubrimiento y que fue trascendental en el desarrollo de la conquista hace su aparición en la Verdadera relación a través de este mito medieval. En este sentido, su presencia en este texto americano tiene una trascendencia fundamental en tanto que nos encontramos ante uno más de los mitos de la antigüedad que fueron trasplantados 
a América, la cual, con este acto de apropiación, se fundaba en los textos sobre las bases de la mitología del Viejo Mundo.

Siguen al Preste Juan el Gran Chino y tras él la reina de Saba, simulando la entrada en Jerusalén para ver a Salomón. Con esta referencia se introduce en la fiesta, y en el texto que la describe, la leyenda bíblica que narra el viaje de la reina de Saba (que gobernaba las tierras del África Oriental), a Jerusalén para conocer al rey Salomón. La reina aparece "con la mayor pompa de camellos, palafrenes y bizarros caballos que se puede imaginar", seguida por cuatro etíopes que casi parecían ir desnudos, ocho damas y dos criados. El conjunto aporta un nuevo exotismo al texto, en el que vemos cómo se van añadiendo las diferentes piezas que componen no solo el mapa geográfico mundial de los pueblos sino también el mapa cultural, con la aparición de la historia, mitos y leyendas de las más diversas civilizaciones que confluyen en la capital mexicana convertida así, para festejar a San Isidro, en un escenario pluricultural. Además, el particular contexto americano aporta sus rasgos propios a ciertas escenas; por ejemplo, cuando vemos aparecer a la reina de Saba bajo otro objeto significativo: un palio indiano, elemento transculturador que convierte esta imagen de la fiesta en ejemplo visual de sincretismo cultural.

Tras la reina de Saba aparece otro de los tópicos iconográficos de la imagen religiosa de Carlos $\mathrm{V}$ y el mito imperial: el rey Salomón, representado en el texto como un personaje bíblico totalmente idealizado, pues para describir su grandeza el relator nos dice que el pliego de papel de esta relación es del todo insuficiente:

Seguíase la gran corte del rey Salomón, cuya grandeza (por no dar lugar este pliego de papel) no se pondrá en particular: cada una de las figuras llevaba por pompa de su acompañamiento todos los reyes que le eran sujetos y pagaban tributo, cada uno con la propiedad del traje que le competía, y todos de varios colores en famosos caballos, con el mayor adorno de pedrería, oro y perlas que se puede imaginar, con gran autoridad de lacayos y pajes de muy lucidas libreas, y la mayor ostentación que se ha visto...

En esta nueva representación del poder lo que resulta más interesante es el paralelismo que se establece entre Salomón -el rey sabio por excelencia-con la imagen previa de Carlos V, es decir, la utilización de un personaje bíblico como vehículo para la expresión de la virtud más relevante del monarca en el contexto del humanismo flamenco, la sabiduría ${ }^{9}$, que fue aclamada por Erasmo en su Educación del Príncipe cristiano como medio para conseguir la gloria verdadera, la maiestas imperial. El rey Salomón va seguido de "todos los reyes que le eran sujetos y pagaban tributo", los cuales a su vez van acompañados de los respectivos "lacayos y pajes" y todo ello "con la mayor ostentación que se ha visto". Por un lado, la escena hace visible una férrea organización estamental, y por otro reproduce la misma estructura superior, supranacional, y de cariz claramente imperial que hemos visto en la sección anterior del desfile. Con ello la propaganda lanzada previamente en la representación de Carlos $\mathrm{V}$-seguido de los consabidos reyes europeos y asiáticos- viene a asimilarse en esta nueva estampa en la que la leyenda bíblica refuerza, con esta identificación implícita del Emperador con Salomón, el mensaje político que está desfilando a través de estos personajes por las calles principales del centro de México.

Aprovechando la espectacularidad material de la imagen, el mensaje político se alía de inmediato con el religioso, cuando a continuación vemos aparecer a tres acompañantes del rey Salomón "sembrando letras con declaración del pensamiento, que era la sabiduría y poder de Salomón". Esas letras lanzadas a los espectadores al paso del rey serían salmos bíblicos o escritos de contenido religioso puesto que, como apunta Juan Rodríguez, eran ofrecidas "a la mucha virtud y santa inocencia de Isidro". Así, la configuración del rey se realiza a través de la fusión entre lo material (indumentaria, objetos, etc.) y la letra escrita. Propagar en México la celebridad de la sabiduría, el poder y la riqueza de Salomón fijada en la Biblia constituiría en esta escena una forma erudita de ensalzar a San Isidro, de mostrar la cultura del autor del texto o del organizador del mismo, y fundamentalmente de reforzar la imagen política de Carlos $\mathrm{V}$ a través del vínculo con un rey bíblico sabio; un vínculo que, como sabemos, no es original de este festejo sino que es un paralelismo tipológico muy recurrido en la iconografía carolina para afianzar características típicas de la imagen de Carlos V, en este caso, la sabiduría (a la que concurre también la aparición de la Reina de Saba ${ }^{10}$ ). Además, la relevancia de esta analogía con Salomón radica en el hecho de que viene a completar en un mismo texto una representación de Carlos $\mathrm{V}$ que abarca las diferentes imágenes con que fue retratado a lo largo del siglo XVI, pues si al principio ha aparecido como héroe guerrero y victorioso sobre sus enemigos -siguiendo las imágenes fijadas por las Bellas Artes-, el vínculo con Salomón lo configura como buen pastor, príncipe virtuoso o rey sabio, idea que -a diferencia de la otra- 
es más bien de raigambre literaria (Checa Cremades, 1987, p. 80). De este modo, la práctica guerrera y la ideología erasmista sobre el pacifismo, que chocaban frontalmente en el proyecto imperial de Carlos $\mathrm{V}^{11}$, aparecen conjugadas en el texto, seguramente con la pretensión de justificar, a través del erasmismo, los requerimientos bélicos de la política imperialista, lo cual resulta especialmente significativo en el espacio de dominación colonial.

Por último, las escenas finales representan el mundo del santo beatificado: labradores con sus hoces por insignia, ángeles arando, la representación de Juan de Vargas -quien fue el propietario y patrón de la finca en la que sirvió San Isidro- y "un carro muy vistoso y de grandísima arquitectura, cuya grandeza requeriría nueva relación", colofón de la grandiosidad de la mascarada $^{12}$. El carro porta una imagen de Nuestra Señora de Atocha y una hechura de San Isidro adorándola, con lo que el santo homenajeado cierra el desfile que, como detalla Juan Rodríguez, tuvo como escenario "las calles más principales de la ciudad", causando gran gusto a todo el pueblo.

\section{CONCLUSIONES}

Como se ha podido comprobar, el aparato propagandístico principal para la comunicación del mensaje político-religioso se encuentra en la estructura general del desfile relatado en el texto objeto de estudio, en el que aparecen los principales representantes del mundo, desde Europa pasando por Oriente Medio y hasta el Lejano Oriente, en un festejo protagonizado por Carlos $\mathrm{V}$ y en homenaje a un santo cristiano, incluyendo de este modo en la celebración tanto a la civilización cristiana como a otras no cristianas. Sobre este fenómeno es importante advertir que esta estructura festiva era muy recurrida en la Península (Zugasti, 2005, p. 63) ${ }^{13}$. Así, este tipo de fiestas religiosas, organizadas en torno a beatificaciones o canonizaciones, se configuraron como manifestaciones ostensibles del triunfo de la fe cristiana, tanto en la Península como en las colonias. Ahora bien, como hemos visto en la presente relación, es evidente que en el espacio americano dicha estructura integradora de todas las civilizaciones y culturas en actos de homenaje a autoridades políticas o eclesiásticas tenía una repercusión crucial, tanto para fortalecer la estratificación social del sistema colonial como para el refuerzo de la fe cristiana, e incluso para la consolidación de la identidad criolla; identidad que se construye sobre la reminiscencia de las entradas triunfales de Carlos V en ciudades hispanas como mecanismo de glorificación de la capital novohispana y sus orígenes.

Así, haciendo funcionar el fin didáctico de toda fiesta religiosa que se celebraba en la América hispánica, en la Verdadera relación el fasto actúa como instrumento para refrendar la fe y asentar las bases de la identidad en el acto social. A modo de síntesis y conclusión, el mensaje religioso se transmite visualmente a lo largo de todo el texto, desde la aparición primera de los mancebos africanos acompañando al labrador, pasando por la representación del Gran Turco o por la escenificación de aquel personaje mítico delegado del cristianismo de la Europa medieval, el Preste Juan de las Indias, hasta la creación de toda la escenografía protagonizada por el rey Salomón y el reparto al público de las letras religiosas en homenaje a San Isidro. Todo ello se funde en el texto con una fuerte codificación política cuyo objetivo último y principal, como ha sido analizado, no es sino el de adherir al entramado social mexicano la imagen imperial, apelando para ello a los tópicos iconográficos de la figura heroica de Carlos V: su identificación con la leyenda bíblica del rey Salomón o su configuración como perfecto caballero cristiano en relación con la tradición medieval caballeresca ${ }^{14}$. En este complejo proceso de asimilación de la historia en el ámbito colonial resultaba imprescindible propagar en la capital novohispana el mito épico de España, porque al mismo tiempo ello permitía glorificar la etapa fundacional de la Nueva España, y por ende asentar la construcción de la identidad sobre unos cimientos históricos egregios. En definitiva, un espectáculo barroco en el que hemos comprobado cómo la escenificación de lo político y lo religioso entrelazados se trasmite a través de la fusión entre cultura material y mensajes escritos que adquieren toda su relevancia para el "engaño a los ojos" y la aceptación del orden colonial; en suma, para la consolidación de las bases del virreinato: el poder monárquico y la estratificación social.

\section{AGRADECIMIENTOS}

Este trabajo forma parte del proyecto de investigación del Ministerio de Economía y Competitividad "En los bordes del archivo, II: escrituras efímeras en los virreinatos de Indias" (FFI2015-63878-C2-2-P). 


\section{NOTAS}

1. Publicado por primera vez en México por Pedro Gutiérrez, el texto nos ha llegado a través de tres transcripciones modernas, dos españolas y una mexicana: la primera fue publicada en El Día, con fecha de 14 de mayo de 1883; la segunda en 1891 por el Conde de las Navas (Juan Gualberto López Valdemoro de Quesada) y por D. Manuel R. Zarco del Valle, bajo el pseudónimo de Espinosa y Quesada, en el libro Cosas de España; y la tercera corrió a cargo de Manuel Romero de Terreros, Marqués de San Francisco, y fue publicada en 1918 en el libro Torneos, mascaradas y fiestas reales en la Nueva España.

2. Sobre las relaciones de sucesos en México colonial véase Rodríguez (1998).

3. Bonet Correa (1986) explica la trascendencia de la evolución que experimentaron los actos festivos en este período, fundamental para comprender el texto objeto de estudio: "Pocos periodos históricos como el barroco fueron tan dados a la fiesta. Desde el otoño de la Edad Media hasta la caída del Antiguo Régimen, con la Revolución francesa y la revolución industrial, la fiesta tendrá una vigencia y un vigor incomparables. Del mundo caballeresco y medieval de los torneos, fastuosos y aristocráticos, con la formación del Estado moderno se pasó al de la fiesta organizada, con mayor participación de los distintos estamentos sociales, al espectáculo para ser admirado por las masas urbanas partícipes de ella y que fácilmente se dejaban dirigir y manipular por agentes tan especializados como fueron los jesuitas u otros directores espirituales" (p. 43).

4. En este sentido, es importante destacar, con Ramos Sosa (1997), un hecho fundamental para comprender la rele-

\section{BIBLIOGRAFÍA}

Alenda y Mira, J. (1903). Relaciones de solemnidades y fiestas públicas de España. Madrid: Sucesores de Rivadeneyra.

Bonet Correa, A. (1986). Arquitecturas efimeras, ornatos y máscaras. El lugar y la teatralidad de la fiesta barroca. En: Díez Borque, J. M. (coord.). Teatro y fiesta en el Barroco. España e Iberoamérica. Madrid: Ediciones del Serbal.

Buxó, J. P. (2007). Poética del espectáculo barroco: el Neptuno alegórico de Sor vancia de las fiestas en la configuración física de las ciudades, y es que "algunas remodelaciones urbanísticas, obras de arquitectura y escultura, tienen su germen en la celebración de grandes fiestas", es decir, que "no toda la arquitectura de la fiesta fue efímera, a veces fue duradera" (pp. 269 y p. 276)

5. Cito por la edición digital del Centro Virtual Cervantes: Disponible en: https:// cvc.cervantes.es/literatura/quijote_ america/mexico/mascara.htm

6. Recordemos que Carlos V fue tres veces coronado: en Aquisgrán en 1520, y dos veces en Bolonia en 1530.

7. La orden fue fundada en $\mathbf{1 4 2 9}$ por Felipe III el Bueno, duque de Borgoña, convirtiéndose en la máxima distinción que podía conceder el rey de España.

8. Juan de Mandeville, a quien se atribuye la invención del nombre del Preste Juan, describió en su Libro de las maravillas del mundo, de mediados del siglo XIV, las tierras fabulosas del Preste Juan y sus batallas con el Gran Kahn.

9. La utilización de estos paralelismos fue fundamental para la legitimación del estado monárquico teológico, tal y como explica Buxó (2007): “las imágenes fantásticas de las personas míticas y las personas reales que se contemplan a sí mismas en el espejo de sus representaciones imaginarias son, como en un desdoblado espectáculo teatral, imágenes actanciales del otro, en tanto signos visibles de unas preclaras virtudes políticas que otros ostentaron en la antigüedad fabulosa o histórica, y héroes verdaderos que se ofrecen a sí mismos a la contemplación de sus nuevos vasallos como actualizaciones tangibles del paradigma ideal" (pp. 53-54).

Juana. En: Farré Vidal, J. (ed.). Teatro y poder en la época de Carlos II. Fiestas en torno a reyes y virreyes. Madrid: Iberoamericana / Vervuert.

Checa Cremades, F. (1987). Carlos V y la imagen del héroe en el Renacimiento. Madrid: Taurus.

Erasmo (1964). Obras escogidas. Madrid: Aguilar.

Gil, J. (1989). Mitos y utopías del descubrimiento. Madrid: Alianza.
10. "La persistencia del tópico es muy grande. Así, por ejemplo, en uno de los arcos triunfales de la entrada en Arras de 1548 se escenifican episodios de la Historia de Gedeón, de la de David, de la de Salomón y la Reina de Saba -alusión a la Sabiduría-..." (Checa Cremades, 1987, p. 153). Sobre la tipificación de Carlos $V$ como rey sabio, vénase también en este mismo libro las pp. 209-211.

11. Recordemos, por ejemplo, los consejos de Erasmo en su Educación del príncipe cristiano, donde erigió a Salomón y a David como ejemplos de la sabiduría del Príncipe: "Quizá a alguno esto le parecerá una pequeñez sin importancia pero tiene alguna, pues importa mucho que los artistas representen al príncipe con la seriedad y el traje más digno de un príncipe sabio y grave" (Erasmo, 1964, p. 111).

12. Sobre el origen de los carros, véase Gisbert (1983).

13. En la festividad que relata Zugasti, celebrada en Segovia en 1615 y organizada para el recibimiento de la princesa Isabela -hija de los reyes de Francia y futura esposa de Felipe IV-, también participan todas las naciones del mundo: salieron "un armenio, un gitano, un persiano [o persa], un alemán, un hebreo, un portugués, un indio y un negro etíope, cada uno con sus pajes vestidos al uso de la tierra" (Alenda y Mira, 1903, vol. I, n.ㅇ 658, p. 181).

14. Octavio Paz (1995) aludió a esta teatralización de la política en el período barroco: "la Edad Barroca teatralizó a la política y convirtió un rito como la entrada de un príncipe en una pantomima popular y en una representación alegórica" (p. 198).

Gisbert, T. (1983). La fiesta y la alegoría en el virreinato peruano. En El arte efímero en el mundo hispánico. $V$ Coloquio del Instituto de Investigaciones Estéticas de la Universidad Nacional Autónoma de México, 23 al 26 de octubre de 1978, Morelia. México: Universidad Nacional Autónoma de México, pp. 145-151.

Hunter, D. E. y Whitten, P. (1981). Enciclopedia de antropología. Barcelona: Bellaterra. 
Maravall, J. A. (1960). Carlos V y el pensamiento político del Renacimiento. Madrid: Instituto de Estudios Políticos.

Paz, O. (1995). Sor Juana Inés de la Cruz o las trampas de la fe. México: Fondo de Cultura Económica.

Ramos Sosa, R. (1997). La fiesta barroca en Ciudad de México y Lima. Historia, 30, pp. 263-286.

Rodríguez Abril, J. (1883). Verdadera relación de una máscara que los artífices del gremio de la platería de México y devotos del glorioso San Isidro el Labrador de Madrid, hicieron en honra de su gloriosa beatificación, por Pedro Gutiérrez, en la calle de Tamba, México, 1621. Publicado por el Conde de las Navas en Co- sas de España, Rasco, Sevilla, 1891. [En línea]. Disponible en https://cvc.cervantes.es/literatura/quijote_america/ mexico/mascara.htm

Rodríguez, D. (1998). Texto y fiesta en la literatura novohispana (1650-1700). México: Universidad Nacional Autónoma de México.

Rojas Garcidueñas, J. (1972). Cervantes y don Quijote. México: Secretaría de Ecuación Pública.

Romero de Terreros, M. (marqués de San Francisco) (1918). Torneos, mascaradas y fiestas reales en la Nueva España. México: Porrua.

Sarmiento Ramírez, I. (2007). Cultura y cultura material: aproximaciones a los conceptos e inventario epistemológico. Anales del Museo de América, 15, pp. 217-236.

Solano, F. de (1990). Fiestas en la Ciudad de México: estudio historiográfico. En Solano, F. de Ciudades hispanoamericanas y pueblos de indios. Madrid: Consejo Superior de Investigaciones Científicas, pp. 247-310.

Zarco del Valle Espinosa, N. R. y López Valdemoro Quesada, J. G. (eds.) (1891). Cosas de España. Sevilla: Rasco.

Zugasti, M. (2005). La alegoría de América en el barroco hispánico: del arte efímero al teatro. Valencia: Pre-Textos. 